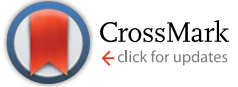

Cite this: J. Mater. Chem. A, 2014, 2 , 19556

Received 14th August 2014

Accepted 7th October 2014

DOI: $10.1039 / c 4 t a 04208 \mathrm{e}$

www.rsc.org/MaterialsA

\title{
Dye sensitized solar cells with cobalt and iodine- based electrolyte: the role of thiocyanate-free ruthenium sensitizers $\uparrow$
}

\author{
Kuan-Lin Wu, $\ddagger^{\mathrm{a}}$ Yue Hu, $\dot{t}^{\mathrm{b}}$ Chun-Tien Chao, ${ }^{\mathrm{a}}$ Ya-Wen Yang, ${ }^{\mathrm{a}}$ Ting-Yun Hsiao, ${ }^{\mathrm{c}}$ \\ Neil Robertson ${ }^{* b}$ and Yun Chi ${ }^{\star a}$
}

\begin{abstract}
Three isomeric Ru(॥) metal complexes with distinctively oriented tpiq ancillary chelates, TFRS-80a, $80 \mathrm{~b}$ and $80 c$, were prepared from the condensation of Ru(4,4'-diethoxycarbonyl-2,2'-bipyridine) ( $p$-cymene $) \mathrm{Cl}$ with tpiqH, i.e. 6-(5-(2,6-bis(hexyloxy)phenyl)thiophen-2-yl)-1-(3-(trifluoromethyl)-1H-pyrazol-5-yl)isoquinoline. Photophysical and electrochemical investigations, together with DFT and TD-DFT calculations, allowed a comprehensive understanding of their basic properties in both solution state and on $\mathrm{TiO}_{2}$ surface. DSC cells with both an ultra-thin layer of transparent $\mathrm{TiO}_{2}(3.6 \mu \mathrm{m})$ and $\mathrm{I}^{-} / \mathrm{I}_{3}^{-}$ electrolyte were fabricated, for which the symmetric sensitizers TFRS-80a and 80c showed better performances ( $\eta=8.37$ and $8.26 \%$ ) over that of the asymmetric counterpart TFRS- $80 \mathrm{~b}(\eta=5.55 \%$ ), the latter suffered from poor dye loading and consequently lowered $J_{\mathrm{SC}}$ and $V_{\mathrm{OC}}$. In sharp contrast, all DSC cells with $\left[\mathrm{Co}(\text { phen })_{3}\right]^{2+/ 3+}$ electrolyte gave superior efficiencies $(\eta=8.36-9.06 \%$ ), for which the thiocyanate-free architecture, the improved light harvesting capability, and the possession of conjugated and bulky 5-(2,6-bis(hexyloxy)phenyl)thiophen-2-yl functional moieties are three primary factors governing the observed results.
\end{abstract}

\section{Introduction}

Photovoltaic technologies are pivotal to the future progression of human societies, among which dye-sensitized solar cells (DSCs) ${ }^{1}$ have already achieved a highest conversion efficiency of $\sim 13 \%$, using $\mathrm{Zn}$ (II) porphyrin sensitizers together with $\mathrm{Co}^{2+/ 3+}$ electrolytes. ${ }^{2}$ A typical DSC consists of a dye that self-assembles onto a mesoporous $\mathrm{TiO}_{2}$ photoanode. The sensitizers can rapidly inject electrons into the conduction band of the $\mathrm{TiO}_{2}$, following excitation by incident solar irradiation. The oxidized sensitizers are then regenerated by redox couples in the electrolyte and become available for the next round of light harvesting, electron injection and reduction. It is believed that better sensitizers would offer a leap in improvement in the overall efficiency of DSC devices.

Organic donor-acceptor dyes with cyanoacrylic anchor are highly competitive due to their potentially simple design,

\footnotetext{
${ }^{a}$ Department of Chemistry and Low Carbon Energy Research Center, National Tsing Hua University, Hsinchu 30013, Taiwan. E-mail: ychi@mx.nthu.edu.tw

${ }^{b}$ EaStCHEM, School of Chemistry, University of Edinburgh, King's Buildings, West Mains Road, Edinburgh EH9 3 JJ, UK.E-mail: Neil.Robertson@ed.ac.uk

${ }^{c}$ Department of Engineering and System Science, National Tsing Hua University, Hsinchu 30013, Taiwan

$\dagger$ Electronic supplementary information (ESI) available. See DOI: 10.1039/c4ta04208e

\$ K.-L. W. and Y. H. contributed equally to this work.
}

synthetic flexibility and scalability. ${ }^{3}$ However, their disadvantage is the poor stability under the combined effects of UV irradiation and water content in the electrolyte, which triggers both the reversion of cyanoacrylic acid to aldehyde, ${ }^{4}$ and photoisomerization of acrylic $\mathrm{C}=\mathrm{C}$ bond. ${ }^{5}$ Recently, a class of organic dyes bearing benzoic acid have ingeniously avoided these degradation pathways and, in combination with filling defects on the $\mathrm{TiO}_{2}$ surface to attenuate interfacial charge recombination, showed excellent efficiency of $>12 \%$ with $\mathrm{Co}^{2+/ 3+}$ electrolytes. $^{6}$

$\mathrm{Ru}(\mathrm{II})$ complexes with thiocyanate ancillaries are known to be both efficient and relatively stable $;^{7}$ hence, they have been subjected to advanced studies aimed towards possible commercialization. $^{8}$ On the other hand, there are growing studies on $\mathrm{Ru}(\mathrm{II})$ sensitizers devoid of thiocyanate ligand, among which van Koten and coworkers have utilized cyclometalate ancillaries to construct the first class of thiocyanatefree $\mathrm{Ru}(\mathrm{II})$ sensitizers, albeit of lower efficiency. ${ }^{9}$ However, their true potential was only realized after Grätzel, who employed the electron deficient 2,4-difluorophenyl pyridinato chelate to construct the sensitizer YE05, showed a prominent conversion efficiency $(\eta)$ of $10.1 \%$ at standard AM 1.5 sunlight. ${ }^{10}$ Later, cyclometalates and other ancillaries were systematically employed by Berlinguette in attempts to expand this class of $\mathrm{Ru}(\mathrm{II})$ sensitizers. ${ }^{\mathbf{1 1}}$

In this content, our group has carried out studies using $\mathrm{N}$ donor ancillaries, such as pyridyl azolate, ${ }^{\mathbf{1 2}}$ 2,6-diazolyl 


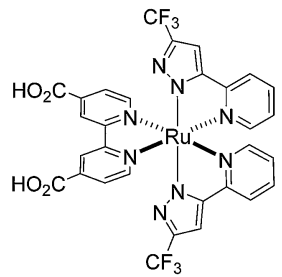

TFRS-1

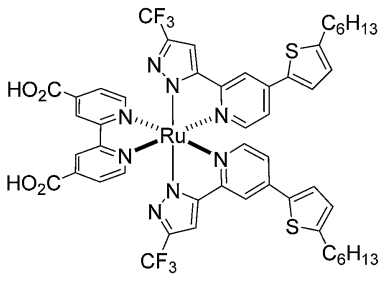

TFRS-2

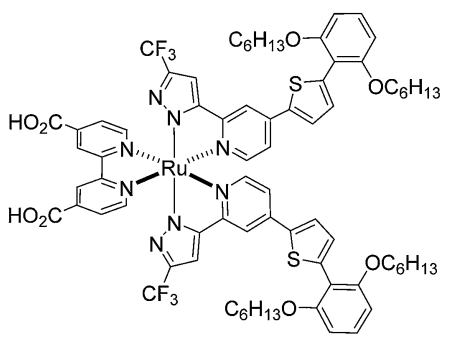

TFRS-42

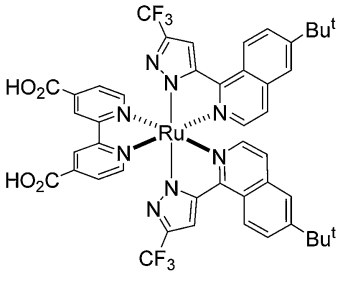

TFRS-52

Scheme 1 Structures of sensitizers TFRS-1, 2, 42 and 52.

pyridine ${ }^{13}$ and 2-azolyl-6-phenylpyridine ${ }^{14}$ to replace the aforementioned cyclometalates. Scheme 1 depicts three $\mathrm{Ru}(\mathrm{II})$ sensitizers with trans-substituted pyrazolate fragments, all derived from their parent complex TFRS-1, showing respectable $\eta$ of $\geq 10 \%$ using $\mathrm{I}^{-} / \mathrm{I}_{3}{ }^{-}$based electrolyte for TFRS-52, ${ }^{15}$ and $\eta$ of $8.71 \%$ using $\left[\mathrm{Co}(\mathrm{bpy})_{3}\right]^{2+/ 3+}$ electrolyte for TFRS-42,
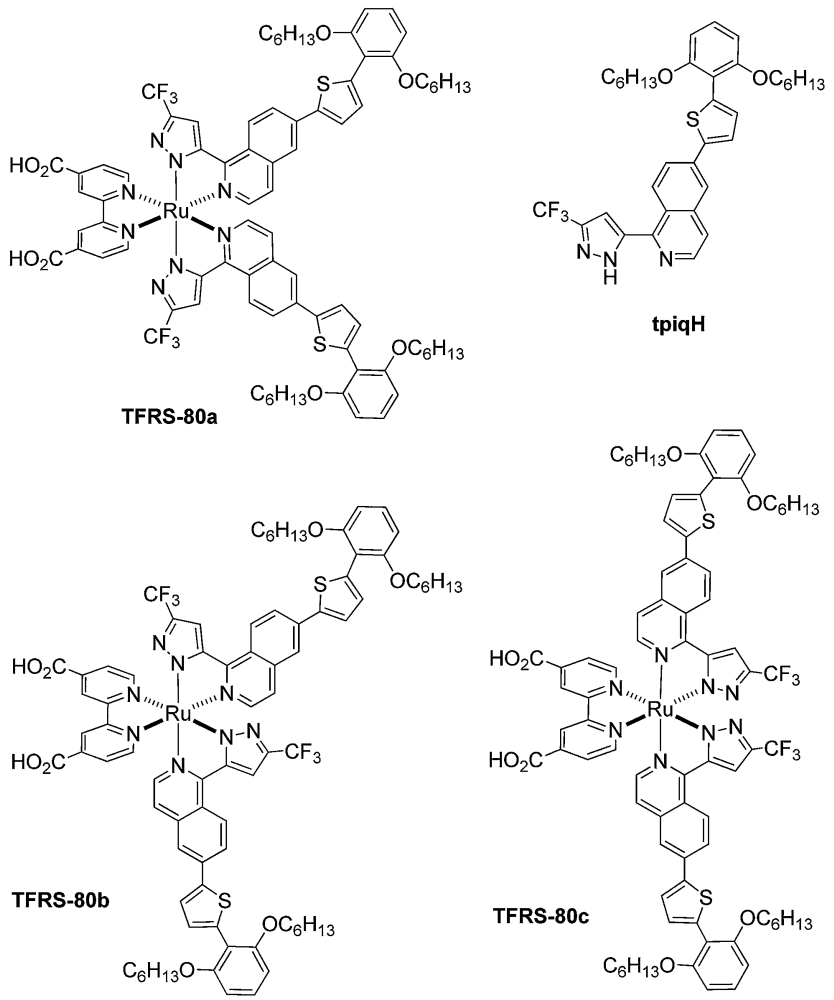

Scheme 2 Structural drawings of tpigH chelate and isomeric sensitizers TFRS-80a, $80 \mathrm{~b}$ and $80 \mathrm{c}$. respectively. ${ }^{16}$ It is notable that TFRS-42 exhibited the highest $\eta$ for the $\mathrm{Co}^{2+/ 3+}$ electrolytic system due to its charge neutrality, greater spatial congestion and absence of thiocyanate ligands, all of which are essential for reducing the recombination across the interface of $\mathrm{TiO}_{2}$ and electrolyte.

These TFRS sensitizers were prepared by coupling of $\mathrm{Ru}$ (diethyl 2,2'-bipyridine-4,4'-dicarboxylate) ( $p$-cymene) $\mathrm{Cl}$ with two equiv. of chelating pyrazole, followed by hydrolysis in basic media. In the absence of any regioselectivity, a maximum of three isomers would be expected, for which the other two structures would differ from all the trans-substituted TFRS dyes shown in Scheme 1 by reshuffling the orientation of the azolate chelates. ${ }^{17}$ Herein, we wish to report the detailed study on the system where all three isomeric sensitizers, TFRS-80a, 80b and 80c, have been isolated and characterized. These sensitizers are derived from a $\pi$-conjugated tpiqH chelate, i.e. 6-(5-(2,6-bis(hexyloxy)phenyl)thiophen-2-yl)-1-(3-(trifluoromethyl)-1H-pyrazol-5-yl)isoquinoline, such that their higher absorptivity and potential for fabrication of DSCs with high $\eta$ of $9.06 \%$ triggered the full determination of their photophysical and electrochemical properties and structure-efficiency relationship of both $\mathrm{I}^{-} / \mathrm{I}_{3}{ }^{-}$and $\mathrm{Co}^{2+/ 3+}$ based dye-sensitized solar cells (Scheme 2).

\section{Results and discussion}

\section{Syntheses}

The pyrazolate ancillary, 5-(2,6-bis(hexyloxy)phenyl)thiophen-2-yl substituted tpiqH chelate, was selected for this investigation due to the large $\pi$-conjugation expected for both the isoquinolinyl fragment and thienyl appendage at the C6 position, resulting in a combined hyperchromic effect and bathochromic shift in the recorded UV/Vis spectra. Moreover, the main function of the 2,6-dihexyloxylphenyl group is to provide both further increased $\pi$-conjugation on the whole molecule and tailored steric encumbrance over the thienyl fragment, such that the formation of intermolecular $\pi$ - $\pi$-stacking interactions around the isoquinolinyl entities can be effectively suppressed. This knowledge is obtained from the molecular design of several efficient DSC sensitizers, on which similar 2,6dialkoxyphenyl groups were incorporated for suppressing aggregation, improving the solubility in organic solvents, and enhancing the overall efficiency of the fabricated DSC devices. ${ }^{18}$

This chelating ancillary is treated with the metal reagent $\mathrm{Ru}\left(4,4^{\prime}\right.$-diethoxycarbonyl-2,2'-bipyridine) ( $p$-cymene) $\mathrm{Cl}$ and the basic promoter KOAc in xylenes, according to the established protocol. All three isomeric products were separated using $\mathrm{SiO}_{2}$ column chromatography, after executing two consecutive elutions using a 1:4 mixture of ethyl acetate and hexane, followed by employment of a $1: 20$ mixture of ethyl acetate and $\mathrm{CH}_{2} \mathrm{Cl}_{2}$. Subsequent hydrolysis of each compound in $\mathrm{NaOH}$-water-acetone mixture afford the carboxylic sensitizers TFRS-80a, 80b and 80c in $32 \%, 11 \%$ and $15 \%$ yields, respectively. It is notable that these isomers represent formation of all three possible structural isomeric $\mathrm{Ru}$ (II) based complexes, for which their structural identification can be achieved according to their ${ }^{1} \mathrm{H}$ and ${ }^{19} \mathrm{~F}$ NMR spectral pattern. Of particular 
importance is the ${ }^{19} \mathrm{~F}$ NMR spectral data, which unambiguous confirmed the symmetric or asymmetric nature of TFRS-80a/80c and TFRS-80b by revealing a single ${ }^{19} \mathrm{~F}$ NMR signal and two signals of equal intensity, respectively.

\section{Photophysical and electrochemical behavior}

The absorption spectra of TFRS-80a, 80b and 80c were measured in DMF and are depicted in Fig. 1, while pertinent numerical data are summarized in Table 1. As can be seen, all sensitizers show strong absorption at $\sim 360 \mathrm{~nm}$ with extinction coefficient $(\varepsilon)$ falling in the range of 5.1-6.2 $\times 10^{4} \mathrm{M}^{-1} \mathrm{~cm}^{-1}$, which is apparently due to the ligand centered $\pi-\pi^{*}$ transition. In addition, there is another lower energy, broad transition centered at $\sim 525 \mathrm{~nm}$, with a slightly lower extinction coefficient of 3.2-3.9 $\times 10^{4} \mathrm{M}^{-1} \mathrm{~cm}^{-1}$. Furthermore, the recorded extinction coefficients are all markedly higher than the corresponding band of N719 $\left(1.4 \times 10^{4} \mathrm{M}^{-1} \mathrm{~cm}^{-1}\right)$ and relevant MLCT band of C101 $\left(1.75 \times 10^{4} \mathrm{M}^{-1} \mathrm{~cm}^{-1}\right)^{19}$ and TG6 $\left(2.3 \times 10^{4} \mathrm{M}^{-1} \mathrm{~cm}^{-1}\right){ }^{20}$ confirming the excellent light harvesting capability in the visible region. The comparisons of experimental UV-visible spectra with the computational simulated oscillator strengths are presented in Fig. S1-S3 of ESI. $\dagger$

DFT and TD-DFT calculations using a DMF polarizable continuum model were carried out, showing that in each case the LUMO is based upon the dicarboxy bipyridine as expected, and that the HOMO is distributed across the Ru orbitals and the entire tpiq ligand (Fig. 2). In particular, we note that this conjugation extends to the thienyl and 2,6-dihexyloxylphenyl fragments in keeping with the intended ligand design and ensuring effective charge separation between electrons injected into the $\mathrm{TiO}_{2}$ and the positive charge on the oxidized dye. It is also apparent that the delocalization of the HOMO differs across the isomer series, with only that of TFRS-80a spread across both tpiq ligands, presumably accounting for the lower HOMO energy for this dye. The TD-DFT calculations reproduced the transition energies of the charge-transfer bands moderately

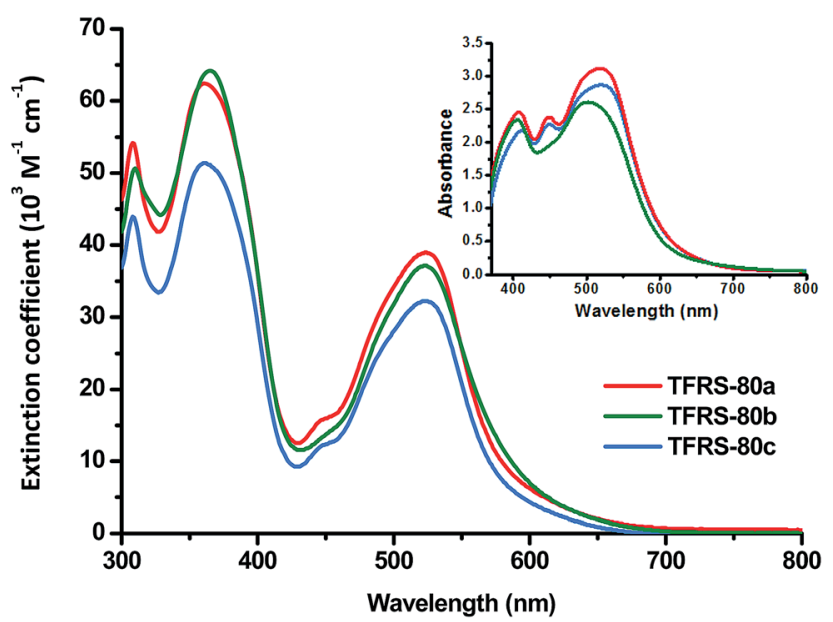

Fig. 1 UV/Vis absorption spectra of various TFRS- 80 sensitizers $(1 \times$ $\left.10^{-5} \mathrm{M}\right)$ in DMF. Inset: spectra of samples adsorbed on $5 \mu \mathrm{m}$ transparent $\mathrm{TiO}_{2}$ thin film.
Table 1 Photophysical and electrochemical data of the studied sensitizers recorded in DMF at RT

\begin{tabular}{lllll}
\hline Dye & $\lambda_{\mathrm{abs}}[\mathrm{nm}]\left(\varepsilon \times 10^{-3}\left[\mathrm{M}^{-1} \mathrm{~cm}^{-1}\right]\right)$ & $E_{\mathrm{ox}}^{\circ \prime a}$ & $E_{0-0}{ }^{b}$ & $E^{\circ * c}$ \\
\hline TFRS-80a & $309(54), 360(62), 523(39)$ & 0.87 & 1.89 & -1.00 \\
TFRS-80b & $310(51), 366(64), 524(37)$ & 0.83 & 1.90 & -1.07 \\
TFRS-80c & $308(44), 362(51), 527(32)$ & 0.78 & 1.87 & -1.09
\end{tabular}

${ }^{a}$ Oxidation potential of dye was measured in DMF with $0.1 \mathrm{M}[\mathrm{TBA}]\left[\mathrm{PF}_{6}\right]$ and with a scan rate of $50 \mathrm{mV} \mathrm{s}^{-1}$. It was calibrated with $\mathrm{Fc} / \mathrm{Fc}^{+}$reference and converted to NHE by addition of $0.63 \mathrm{~V} .{ }^{b} E_{0-0}$ was determined from the intersection of the absorption and the tangent of emission peak in DMF. ${ }^{c} E^{\circ / *}=E_{\mathrm{ox}}^{\circ \prime}-E_{0-0}$.

well, with the results sufficient to give insight into the orbital origins of transitions. The $525 \mathrm{~nm}$ charge transfer band in each case (calculated at around $480 \mathrm{~nm}$ ) originates from a mixture of the $\mathrm{Ru}(\mathrm{II})$ metal core and the pyrazolate to dicarboxy bipyridine, i.e. a mixing of MLCT and LLCT transitions, in a way analogous to the assignment made for other TFRS sensitizers. ${ }^{12 b}$

In the context of DSC application, further enhancements in absorption were observed upon depositing these sensitizers on the $\mathrm{TiO}_{2}$ surface, such that all of the absorptions broadened substantially, the recorded spectra showed an absence of the semi-transparent region centered at $430 \mathrm{~nm}$ recorded in DMF solution, as well as red-shifting of the lowest energy absorption peak maxima to $\sim 700 \mathrm{~nm}$. We speculate that such a broadened spectral profile is beneficial to the competitive harvesting of shorter wavelength irradiation, ${ }^{21}$ particular for DSC devices that utilize the $\mathrm{I}^{-} / \mathrm{I}_{3}{ }^{-}$based electrolytes.

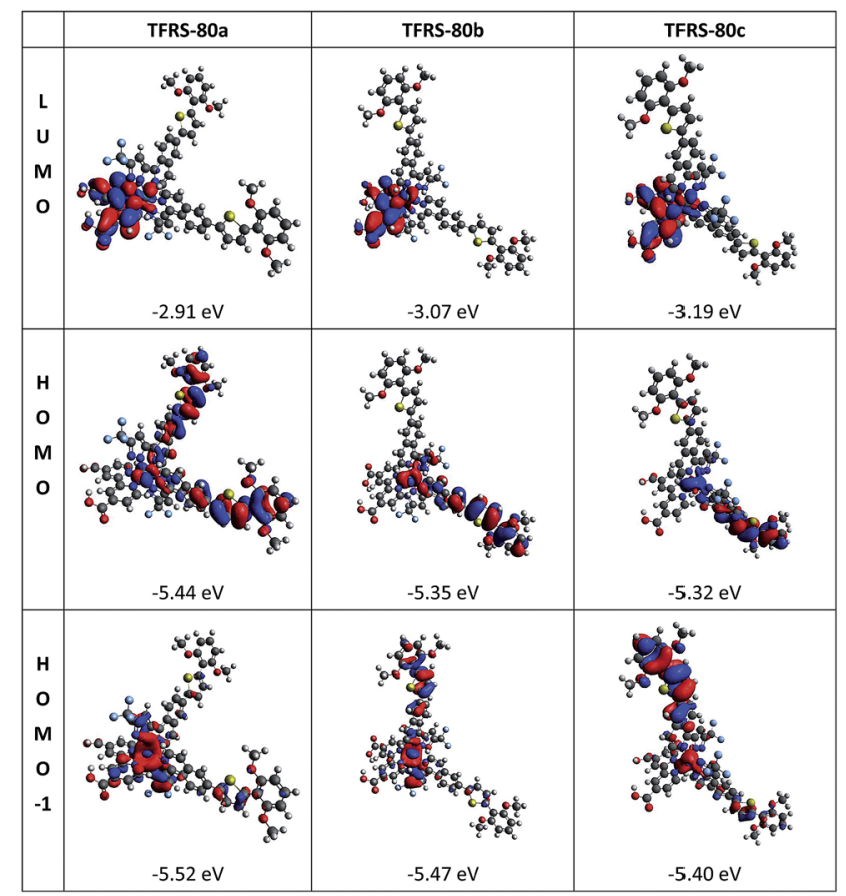

Fig. 2 Molecular orbital distributions and energy of Ru(॥) sensitizers (isodensity $=0.020$ a.u.). 
Cyclic voltammetry was conducted to reveal the variation in electrochemical potentials among the three isomers, and to verify whether the oxidation potential of the ground state $\left(E_{\mathrm{ox}}^{\circ \prime}\right)$ matches the redox potential of the redox mediators. As shown in Table 1, the oxidation potential of the isomers follows the trend of TFRS-80c $<\mathbf{8 0 b}<\mathbf{8 0 a}$ which are reproduced well by the calculated HOMO energies shown by the computational results (see Tables $\mathrm{S} 1-\mathrm{S} 3 \dagger)$. The $E_{\mathrm{Ox}}^{\circ \prime}$ is attributed to the $\mathrm{Ru}(\mathrm{II})$ metal oxidation, and appeared in the range of 0.78-0.87 V (vs. NHE, normal hydrogen electrode), all more positive than that of $\mathrm{I}^{-} / \mathrm{I}_{3}{ }^{-}$ redox couple $\left(E^{\circ}=c a .0 .4 \mathrm{~V}\right)$ and the redox potential of the $\left[\mathrm{Co}(\text { phen })_{3}\right]^{2+/ 3+}\left(E^{\circ}=c a .0 .62 \mathrm{~V}\right.$ vs. NHE $)$. The limited variation

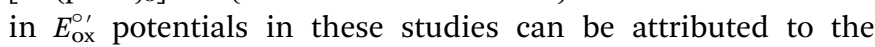
identical local coordination environment around the central $\mathrm{Ru}(\mathrm{II})$ atom, with the small differences attributed to different amounts of delocalization and stabilization of the HOMO. In addition, the zero-zero transition energy $\left(E_{0-0}\right)$ or band gap was determined from the intersection of the absorption and normalized emission spectra. From this, the excited-state oxidation potential $\left(E^{\circ / *}\right)$ is estimated from the difference of $E_{\mathrm{Ox}}^{\circ \prime}$ and $E_{0-0}$, from which the calculated values of -1.00 to $-1.09 \mathrm{~V}$ (vs. NHE) were obtained. Since all of the $E^{\circ *}$ are significantly more negative than the conduction band edge of the $\mathrm{TiO}_{2}$ electrode $\left(E_{\mathrm{CB}} \sim-0.2\right.$ and $-0.5 \mathrm{~V} v s$. NHE), ${ }^{22}$ this confirms that efficient electron injection from the excited sensitizer to the conduction band of $\mathrm{TiO}_{2}$ should occur.

To probe the longer-term stability of the dye oxidized state we carried out spectroelectrochemical studies of each dye in solution upon oxidation (Fig. S4-S6†). It was apparent that TFRS-80c showed the best isosbestic points during the oxidation and was more fully returned to the starting spectrum upon reduction in comparison with either TFRS-80a or TFRS-80b. We have previously suggested the possibility of some isomerization within this type of dye series upon oxidation, ${ }^{17}$ which may also provide an explanation in this case. We note however, that as for previous TFRS-2 and TFRS-52 dyes, the oxidative stability was much higher than we have observed for thiocyanate-containing dyes such as N3. ${ }^{17}$

To further clarify the influence of the dye structure on the solar cell performance (described in the next section), we carried out electrochemical studies of the dyes bound to mesoporous $\mathrm{TiO}_{2}$ films. Since the electrochemical window used lies entirely within the band gap of the $\mathrm{TiO}_{2}$, the $\mathrm{TiO}_{2}$ remains insulating and the redox occurs via a hole-diffusion process starting from the base of the film where dye is in contact with the FTO electrode. Firstly, we observe excellent reversibility of the redox process for all three isomers (Fig. S7-S9†) with little change between redox cycles 1 to 51 confirming these as stable sensitizers. This observation is different from that of TFRS-2 and 52, for which the asymmetric isomer $\mathbf{b}$ is found to be more stable versus the respective isomer a. ${ }^{17}$ Moreover, the quantity of dye uptake was observed to be TFRS-80a $>\mathbf{c}>\mathbf{b}$, (Table S4 $\dagger$ ) consistent with that observed during DSC fabrication (see below). Furthermore, following previously-described procedures and equations listed in ESI, $\dagger$ the maximum observed current and dye concentration were used to calculate a holediffusion coefficient for the case of each dye and these were observed to be in the order TFRS-80a $>\mathbf{8 0 b}>\mathbf{8 0 c}(4.21,1.28$ and $0.203 \times 10^{-10} \mathrm{~cm}^{2} \mathrm{~s}^{-1}$ respectively). These values are all $1-3$ orders of magnitude lower than typical values reported for other $\mathrm{Ru}$ and organic dyes. ${ }^{23}$ It seems likely that this arises due to success of the design strategy whereby the 2,6-dihexyloxylphenyl on the tpiq ligand can suppress $\pi-\pi$ interactions and avoid aggregation. In addition, the order of the values among the isomers further supports this conclusion, since TFRS-80a, 80b and 80c have respectively zero, one and two tpiq arms in the plane of the surface to minimize dye-dye electronic interactions.

\section{Device characteristics}

The photovoltaic properties of these sensitizers were examined, for which the details of cell fabrication and data measurements are depicted in the Experimental section. All cells were fabricated using $3.6 \mu \mathrm{m}(20 \mathrm{~nm})+3.5 \mu \mathrm{m}(400 \mathrm{~nm})$ of mesoporous $\mathrm{TiO}_{2}$ thin film. The photocurrent-voltage characteristics were summarized in Tables 2 and 3. Three electrolyte solutions were employed for these studies; the first (i.e. electrolyte I-A) consisted of $0.6 \mathrm{M}$ 1,2-dimethyl-3-propylimidazolium iodide (DMPII), $0.05 \mathrm{M} \mathrm{I}_{2}$, and 0.5 $\mathrm{M} t$-butylpyridine (TBP) in acetonitrile, while the second (i.e. Co(phen) $\left.)_{3}\right]^{2+/ 3+}$ electrolyte Co-phen) and the third (i.e. electrolyte I-B) contained $0.45 \mathrm{M}\left[\mathrm{Co}(\mathrm{phen})_{3}\right][\mathrm{TFSI}]_{2}$, $0.15 \mathrm{M}\left[\mathrm{Co}(\text { phen })_{3}\right][\mathrm{TFSI}]_{3}, 0.15 \mathrm{M}$ LiTFSI, $0.8 \mathrm{M}$ TBP in acetonitrile, as well as $0.45 \mathrm{M}$ DMPII, 0.05 $\mathrm{M} \mathrm{I}_{2}, 0.15 \mathrm{M}$ LiI, 0.8 M TBP in acetonitrile, respectively. The electrolyte I-A possesses no $\mathrm{Li}^{+}$, while both Co-phen and $\mathrm{I}-\mathrm{B}$ contain $0.15 \mathrm{M}^{\circ} \mathrm{Li}^{+}$cation in electrolyte, such that they can provide an intimate comparison between cell characteristics of the cobalt and iodine based redox couples. Comparative studies on cells with both $\mathrm{I}^{-} / \mathrm{I}_{3}{ }^{-}$ and $\mathrm{Co}^{2+/ 3+}$ electrolytes are starting to gain momentum, inspired by the recent report that the $\mathrm{Co}^{2+/ 3+}$ cells have shown promising photostability under full sun solar illumination. ${ }^{24}$

For the DSCs using electrolyte I-A, TFRS-80a exhibited a $J_{\text {SC }}$ of $12.93 \mathrm{~mA} \mathrm{~cm}^{-2}$, a $V_{\mathrm{OC}}$ of $890 \mathrm{mV}$, and a fill factor (FF) of 0.727 , while TFRS-80c gave performance data of $12.41 \mathrm{~mA} \mathrm{~cm}{ }^{-2}, 880$ $\mathrm{mV}$ and 0.756 , respectively. Their overall conversion efficiencies $(\eta)$ were calculated to be $8.37 \%$ and $8.26 \%$, hence both are superior to that obtained for the asymmetric sensitizer TFRS80b, with $J_{\mathrm{SC}}=9.81 \mathrm{~mA} \mathrm{~cm}^{-2}, V_{\mathrm{OC}}$ of $780 \mathrm{mV}, \mathrm{FF}=0.725$ and $\eta$ $=5.55 \%$. Since the mixture of isomers $80 \mathrm{a}$ and $80 \mathrm{c}$ can be easily

Table 2 Performance characteristics for DSCs based on $\mathrm{I}^{-} / \mathrm{I}_{3}^{-}$electrolyte I-A under AM 1.5G irradiation ${ }^{a}$

\begin{tabular}{lcllll}
\hline Dye & $J_{\mathrm{SC}}\left[\mathrm{mA} \mathrm{cm}^{-2}\right]$ & $V_{\mathrm{OC}}[\mathrm{mV}]$ & $\mathrm{FF}$ & $\eta[\%]$ & Dye loading $^{b}$ \\
\hline TFRS-80a & 12.93 & 890 & 0.727 & 8.37 & 1.72 \\
TFRS-80b & 9.81 & 780 & 0.725 & 5.55 & 1.03 \\
TFRS-80c & 12.41 & 880 & 0.756 & 8.26 & 1.21 \\
TFRS-80ac & 13.12 & 870 & 0.731 & 8.34 &
\end{tabular}

${ }^{a}$ All devices were fabricated using methods depicted in the Experimental section. ${ }^{b}$ Dye desorption experiment was performed using $1 \mathrm{M}$ TBAOH in water-MeOH $(\mathrm{v} / \mathrm{v}, 1: 1)$. The dye loading is in unit of $10^{-7} \mathrm{~mol} \mathrm{~cm}{ }^{-2}$. 
Table 3 Performance characteristics for DSCs based on $\mathrm{Co}^{2+/ 3+}$ electrolyte Co-phen and $\mathrm{I}^{-} \mathrm{I}_{3}^{-}$electrolyte $\mathrm{I}-\mathrm{B}$, under AM $1.5 \mathrm{G}$ irradiation

\begin{tabular}{llllll}
\hline Dye & Electrolyte & $J_{\text {SC }}\left[\mathrm{mA} \mathrm{cm}^{-2}\right]$ & $V_{\text {OC }}[\mathrm{mV}]$ & FF & $\eta[\%]$ \\
\hline TFRS-80a & Co-phen & 13.44 & 840 & 0.757 & 8.55 \\
& I-B & 14.49 & 780 & 0.668 & 7.55 \\
TFRS-80b & Co-phen & 13.30 & 820 & 0.766 & 8.36 \\
& I-B & 10.39 & 680 & 0.681 & 4.80 \\
TFRS-80c & Co-phen & 14.32 & 840 & 0.754 & 9.06 \\
& I-B & 14.84 & 730 & 0.651 & 7.06 \\
\hline
\end{tabular}

separated from 80b, but separation of 80a and 80c required repeated column chromatography, from the point view of practical application we therefore attempted DSC fabrication using the naturally occurring mixture of TFRS-80a and 80c, for which the recorded characteristics were $J_{\mathrm{sc}}=13.12 \mathrm{~mA} \mathrm{~cm}^{-2}$, $V_{\mathrm{OC}}$ of $870 \mathrm{mV}, \mathrm{FF}=0.731$, and $\eta=8.34 \%$, respectively. These data ( $c f$. TFRS-80ac) showed no difference from cells fabricated using each of the pure samples, suggesting the retention of all device performances.

Fig. 3a exhibits the incident photon-to-current conversion efficiency (IPCE) action spectra recorded using $\mathrm{I}^{-} / \mathrm{I}_{3}{ }^{-}$electrolyte I-A. The onset of the IPCE spectra of TFRS-80a, 80c, and the mixture of TFRS-80a and 80c are all close to $\sim 780 \mathrm{~nm}$, and with excellent IPCE performance in the range from 400 to $560 \mathrm{~nm}$, among which the highest IPCE of $78 \%$ is recorded at around 530 $\mathrm{nm}$, while TFRS-80b showed a notably lowered IPCE of only $51 \%$ at the same position. Apparently, the symmetrical TFRS-80a and 80c exhibit much better IPCE action spectra as well as superior $J-V$ characteristics, versus those exhibited by the asymmetric stereoisomer $\mathbf{8 0 b}$. It appears to us that the significantly reduced dye loading of 80b on the $\mathrm{TiO}_{2}$ surface, which not only reduced the absorptivity of $\mathbf{8 0 b}$ on $\mathrm{TiO}_{2}$ (Fig. 1) but also increased the charge recombination at the $\mathrm{TiO}_{2} /$ electrolyte interface, is the major contributing factor for the poor overall conversion efficiency detected.

Next, the photovoltaic performance of these sensitizers was evaluated by using $\left.\mathrm{Co}(\text { phen })_{3}\right]^{2+/ 3+}$ based redox mediator in acetonitrile solution (i.e. Co-phen). $\mathrm{A}^{-1 O_{2}}$ blocking layer was pre-deposited on FTO glass using an aqueous $\mathrm{TiCl}_{4}$ solution. This measure is for retarding charge recombination between FTO and the $\mathrm{Co}^{2+/ 3+}$ mediator in electrolyte. ${ }^{25}$ Interestingly, the DSC device fabricated using TFRS-80c and $\left[\mathrm{Co}(\text { phen })_{3}\right]^{2+/ 3+}$ redox couple afforded the highest performance characteristics of $J_{\mathrm{SC}}=14.32 \mathrm{~mA} \mathrm{~cm}{ }^{-2}, V_{\mathrm{OC}}=840 \mathrm{mV}$, and $\mathrm{FF}=0.754$, corresponding to an overall $\eta=9.06 \%$ under AM $1.5 \mathrm{G}$ one sun irradiation. We attribute this to the diaxial arrangement of the isoquinolinyl substituents on the $\mathrm{Ru}(\mathrm{II})$ metal complex, on which the bulky 2,6-dialkoxyphenyl group is expected to form a closely packed insulation layer, as they are now lying directly on top of the $\mathrm{TiO}_{2}$ electrode surface. ${ }^{26}$ This spatial arrangement is expected to be very effective in preventing the oxidized $\mathrm{Co}^{3+}$ species from approaching close to the $\mathrm{TiO}_{2}$ surface in comparison with the other isomers $\mathbf{8 0 a}$ and $\mathbf{8 0 b}$, for which there is at least one 2,6-dialkoxyphenyl group per molecule orientated
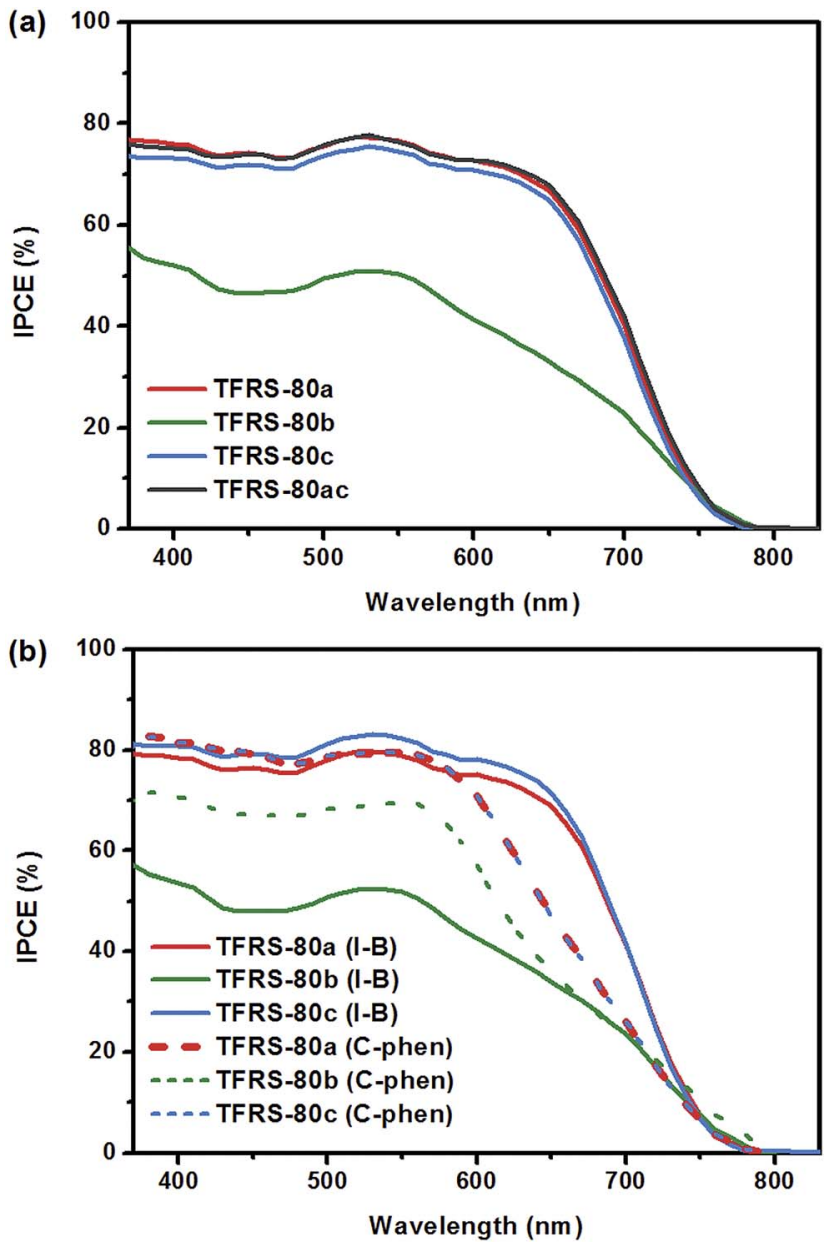

Fig. 3 IPCE action spectra for DSC cells fabricated using (a) electrolyte $\mathrm{I}-\mathrm{A}$ and (b) electrolyte Co-phen and another $\mathrm{I}^{-} / \mathrm{I}_{3}^{-}$electrolyte $\mathrm{I}-\mathrm{B}$ under AM1.5 solar irradiation.

further away from the $\mathrm{TiO}_{2}$ surface, and cannot be effective in suppressing the charge recombination against the accumulated, oxidized $\mathrm{Co}^{3+}$ metal species.

For a further comparison, all sensitizers were subjected to DSC fabrication using the $\mathrm{I}^{-} / \mathrm{I}_{3}{ }^{-}$reference electrolyte (i.e. electrolyte I-B) under identical cell parameters. As can be seen, the overall efficiencies span the range $4.80-7.55 \%$, among which the best one is that fabricated using TFRS-80a. In comparison across the different electrolytes, these data remain $1.0 \%$ lower than those documented for the cell fabricated using the corresponding sensitizer and the $\left[\mathrm{Co}(\text { phen })_{3}\right]^{2+/ 3+}$ electrolyte Cophen. For TFRS-80c, the difference increases to approx. 2.0\%, which is even greater. Moreover, the DSC device fabricated using TFRS-80b and $\mathrm{I}^{-} / \mathrm{I}_{3}{ }^{-}$electrolyte I-B showed the worst overall $\eta$ of $4.80 \%$. These data are much inferior to those observed for the $\mathrm{Co}^{2+/ 3+}$ based cell, with performance data of $J_{\mathrm{SC}}$ $=13.30 \mathrm{~mA} \mathrm{~cm}{ }^{-2}, V_{\mathrm{OC}}=820 \mathrm{mV}$, and $\mathrm{FF}=0.766$, corresponding to an overall $\eta=8.36 \%$. The latter result is probably due to the effective insulating power of this sensitizer against the bulky $\mathrm{Co}^{3+}$ metal species, leading to the more effective suppression of charge recombination. In addition, the lowered 
efficiencies of all $\mathrm{I}^{-} / \mathrm{I}_{3}{ }^{-}$based DSCs can be traced to the inferior $V_{\text {OC }}$, mainly caused by the greater loss-in-potential for the $\mathrm{I}^{-} / \mathrm{I}_{3}{ }^{-}$ redox couple versus the $\mathrm{Co}^{2+/ 3+}$ electrolyte.

Moreover, the cell efficiency of TFRS-80b is $\sim 2.5 \%$ lower than those of the symmetric counterparts, i.e. TFRS-80a and TFRS-80c, upon using the $\mathrm{I}^{-} / \mathrm{I}_{3}{ }^{-}$based electrolytes $\mathrm{I}-\mathrm{A}$ and $\mathrm{I}-\mathrm{B}$. On the other hand, the TFRS-80b sensitizer showed a much smaller difference of $0.7 \%$ in efficiency upon switching to $\mathrm{Co}^{2+/ 3+}$ electrolyte, compared with the best TFRS-80c. Since all of these sensitizers have essentially identical spectroscopic and electrochemical properties, this large variation can only be explained by the inferior dye-loading for TFRS-80b that generated a larger number of voids on the $\mathrm{TiO}_{2}$ surface. Accordingly, the $\mathrm{I}_{3}{ }^{-}$ion is much smaller and can penetrate much deeper into the dye layer versus that of $\mathrm{Co}^{2+/ 3+}$ electrolyte, giving much greater charge recombination and the greater difference in efficiencies.

Fig. $3 \mathrm{~b}$ exhibits the incident photon-to-current conversion efficiency (IPCE) action spectra recorded using the electrolytes Co-phen and I-B. Integration of the IPCE spectra yields the calculated $J_{\mathrm{SC}}$ data which are in good agreement with the experimental values. It is also notable that the $\mathrm{Co}^{2+/ 3+}$ electrolyte exhibited the higher photocurrent response from 370 to $440 \mathrm{~nm}$ versus that of the $\mathrm{I}^{-} / \mathrm{I}_{3}{ }^{-}$electrolyte, which is ascribed to the lower molar absorption coefficients of the $\mathrm{Co}^{2+/ 3+}$ complexes in the high energy region compared with the $\mathrm{I}^{-} / \mathrm{I}_{3}{ }^{-}$redox couple. Concurrently, similar to other reported $\mathrm{Ru}(\mathrm{II})$ sensitizers, we also observed a degradation of the photocurrent response in the lower energy region when switching to the $\mathrm{Co}^{2+/ 3+}$ electrolyte. ${ }^{27}$ This phenomenon is probably due to the poor dye regeneration efficiencies caused by the diminishing of the overpotential for dye regeneration.

For a closer comparison, the best recorded efficiency of TFRS-80 series obtained in this study (9.06\%) is slightly higher than that of recently reported tris-heteroleptic $\mathrm{Ru}(\mathrm{II})$ sensitizers with $2^{\prime}, 6^{\prime}$-dimethoxy-2,3'-bipyridine cyclometalate $(\eta=8.6 \%) .{ }^{27 a}$ In turn, both data are superior to the thiocyanate-free $\mathrm{Ru}$ (II) sensitizer with ppy- $\left(\mathrm{CF}_{3}\right)_{2}$ cyclometalate $(\eta=5.5 \%),{ }^{11 a}$ and traditional thiocyanate-containing $\mathrm{Ru}(\mathrm{II})$ sensitizers, such as: N719 $(\eta=1.8 \%)$ and Z907 $(\eta=6.5 \%),{ }^{27 c}$ Z907 with co-grafting phosphonic acid $(\eta=8.4 \%),{ }^{27 b}$ and $\mathbf{C 1 0 1}(\eta=3.6 \%)$ and TT-230 $(\eta=1.8 \%){ }^{28}$ It is notable that the TT-230 dye was even functionalized with the cyclopenta(2,1- $\left.b: 3,4-b^{\prime}\right)$ dithiophene moieties, ${ }^{29}$ which were widely used in organic push-pull dyes for extending the optical response, retarding charge recombination and suppressing dark current, but is still unable to boost its performances. On the other hand, DSCs with $\mathrm{Co}^{2+/ 3+}$ electrolytes are known to display higher solar cell efficiency, if the employed organic sensitizers were decorated with adequate bulky and electron donating appendages ${ }^{30}$ and with rigidified skeletal structure, ${ }^{31}$ to bring forth the anticipated enhancement in both $J_{\mathrm{SC}}$ and $V_{\mathrm{OC}}$, by avoiding the aggregation and facilitating the photo-induced electron transfer process.

To gain further insight into the rates of interfacial recombination of electrons from the $\mathrm{TiO}_{2}$ conduction band to the redox mediators in the electrolyte, variation of the $\mathrm{TiO}_{2}$ conduction band potential was accessed by measuring the capacitance for three DSC devices at each $V_{\text {OC }}$ using the charge extraction (CE) method and intensity-modulated photovoltage spectroscopy (IMVS) measurement. Comparing that of TFRS80a and 80c, a lower $V_{\text {OC }}$ for TFRS-80b is noticed (see Table 3). As shown in Fig. 4a, the CE results indicate that the $\mathrm{TiO}_{2}$ conduction band potential of the devices with the Co-phen
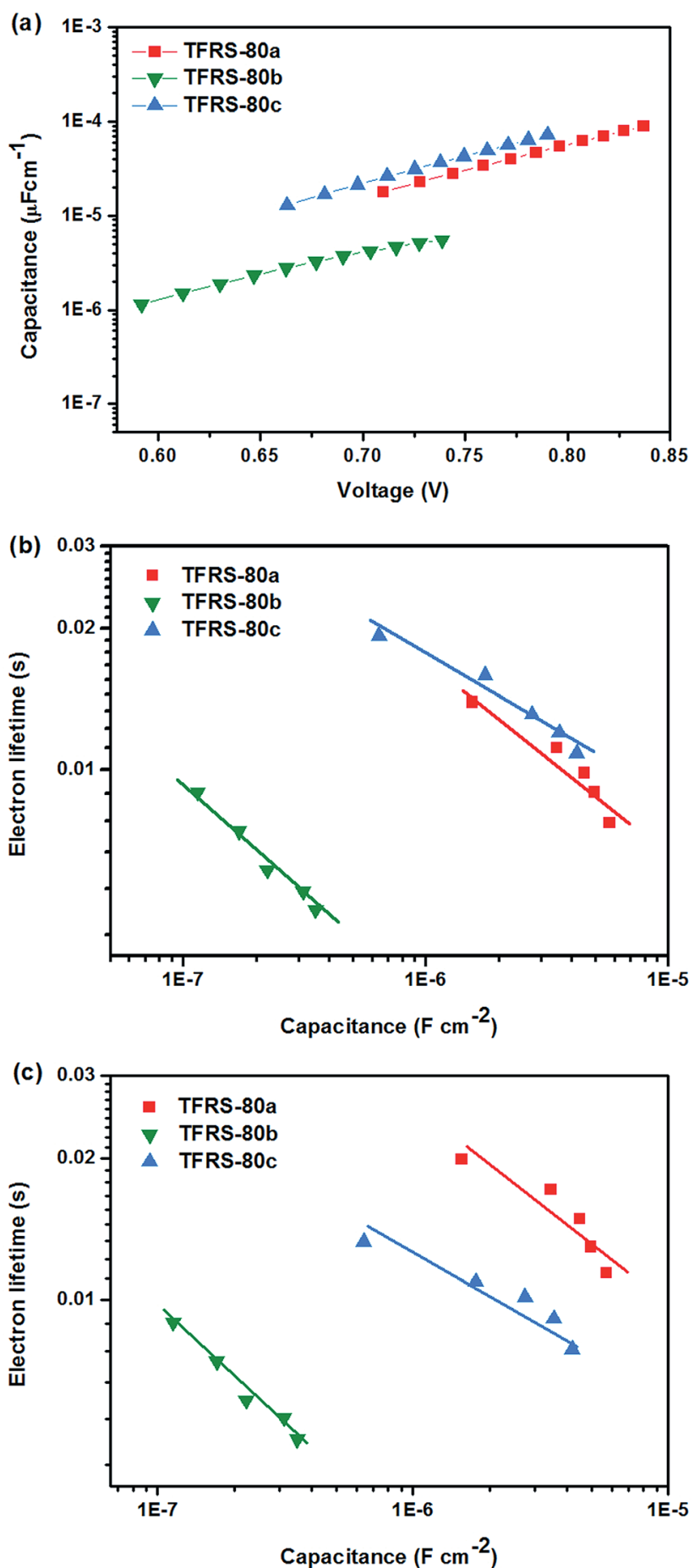

Fig. 4 (a) Electron density versus voltage deduced from charge extraction measurement; (b) IMVS measurement for cells using the electrolyte Co-phen and (c) IMVS measurement for cells using $\mathrm{I}^{-} / \mathrm{I}_{3}^{-}$ electrolyte I-B. 
electrolyte showed a systematic upward shift in the order TFRS-80b $<$ 80c $<$ 80a, consistent with the variation of their $V_{\text {OC. }}{ }^{32}$ Fig. $4 \mathrm{~b}$ and $\mathrm{c}$ show plots of electron lifetime under five different light intensities. The results indicate a systematic trend with the electron lifetime showing an order of TFRS-80c $>\mathbf{8 0 a}>\mathbf{8 0 b}$ for the Co-phen electrolyte and the order of TFRS-80a $>\mathbf{8 0 c}>\mathbf{8 0 b}$ for the electrolyte I-B, respectively. These trends correspond to the degree of charge recombination, and are also consistent with the variation of $V_{\mathrm{OC}}$ for these devices. Normally, the electron lifetime has the opposite trend versus charge recombination. Longer electron lifetime would correspond to smaller charge recombination loss and higher $V_{\text {OC }}$ in solar cells. Additionally, the electron lifetime of TFRS-80c is the highest for all the cells using $\mathrm{Co}^{2+/ 3+}$ based electrolyte. Thus, this proves the non-accumulation of $\mathrm{Co}^{3+}$ species in the proximity of $\mathrm{TiO}_{2}$ surface and the decrease in charge recombination due to the efficient blocking effect of TFRS sensitizers.

\section{Conclusion}

To sum up, we have designed and prepared a series of thiocyanate-free Ru(II) sensitizers, i.e. TFRS-80a, 80b and 80c, all with similar electrochemical properties and identical optical response under simulated one sun illumination, but showing varied steric impediment upon depositing on $\mathrm{TiO}_{2}$ surface according to the coordination orientation of the tpiq ancillaries. Among the photophysical and electrochemical parameters collected, the hole-diffusion coefficients are the most important, which follow the trend of TFRS-80a $>80 \mathrm{~b}>\mathbf{8 0 c}(4.21,1.28$ and $\left.0.203 \times 10^{-10} \mathrm{~cm}^{2} \mathrm{~s}^{-1}\right)$. This trend supports the effective blockage of $\pi-\pi$ interactions by 2,6-dihexyloxylphenyl substituents, since TFRS-80a, 80b and 80c have respectively zero, one and two tpiq arms in position to minimize dye-dye interactions on the $\mathrm{TiO}_{2}$ surface.

DSCs with $\mathrm{I}^{-} / \mathrm{I}_{3}{ }^{-}$electrolyte were first fabricated, among which the TFRS-80a and TFRS-80b showed the highest and the lowest efficiencies of $\eta=8.37$ and $5.55 \%$, for which the large variation was mainly determined by the amount of dye uptake and hence, give decreased light harvesting capability and enhanced charge recombination across the $\mathrm{TiO}_{2}$-dye-electrolyte interface for the asymmetric TFRS-80b. In sharp contrast, DSCs with $\left[\mathrm{Co}(\text { phen })_{3}\right]^{2+/ 3+}$ electrolyte showed much superior efficiencies for all TFRS-80 sensitizers and, most importantly, the detected efficiency increased to $\eta=9.06 \%$ in the symmetrical TFRS-80a. Their advantages are apparently due to the combination of several factors, namely: (i) charge neutrality, (ii) absence of thiocyanate ligands, (iii) enhanced dye loading, and (iv) adequate spatial impediment upon depositing on $\mathrm{TiO}_{2}$ surface. All these contributing factors are essential for preventing the strong association to the $\mathrm{Co}^{2+/ 3+}$ mediator, which therefore reduces the charge recombination across the interface of $\mathrm{TiO}_{2}$ and electrolyte. The knowledge gained in this study should be of help to the future optimization of $\mathrm{Ru}$ (II) metal based sensitizers for DSC cells employing various $\mathrm{Co}^{2+/ 3+}$ based mediators.

\section{Experimental section}

\section{General procedures}

All reactions were performed under nitrogen. Solvents were distilled from appropriate drying agents prior to use. Commercially available reagents were used without further purification. All reactions were monitored by TLC with precoated silica gel plates (Merck, $0.20 \mathrm{~mm}$ with fluorescent indicator UV254). Compounds were visualized with UV irradiation at 254 or $365 \mathrm{~nm}$. Flash column chromatography was carried out using silica gel obtained from Merck (230-400 mesh). Mass spectra were obtained on a JEOL SX-102A instrument operating in electron impact (EI) or fast atom bombardment (FAB) mode. ${ }^{1} \mathrm{H}$ and ${ }^{19} \mathrm{~F}$ NMR spectra were recorded on a Bruker-400 instrument. Photophysical data were obtained using an Edinburgh Fluorescence spectrometer FLS928P. Details of the synthetic protocols for the tri-dentate ancillary chelates and the procedures for the DFT calculations are all given in the ESI. $\dagger$

\section{Synthesis of TFRS-80a, 80b and 80c}

A xylene solution of 6-(5-(2,6-bis(hexyloxy)phenyl)thiophen-2yl)-1-(3-(trifluoromethyl)-1H-pyrazol-5-yl)isoquinoline $(113 \mathrm{mg}$, $0.209 \mathrm{mmol}), \mathrm{Ru}($ diethyl-2,2'-bipyridine-4,4'-dicarboxylate) ( $p$ cymene)Cl (60 mg, $0.104 \mathrm{mmol}$ ), and KOAc (52 mg, $0.531 \mathrm{mmol}$ ) was heated at reflux under $\mathrm{N}_{2}$ for $6 \mathrm{~h}$. After the removal of solvent under vacuum, the residue was dissolved in $\mathrm{CH}_{2} \mathrm{Cl}_{2}$ and washed with water $(3 \times 20 \mathrm{~mL})$. Concentration of this $\mathrm{CH}_{2} \mathrm{Cl}_{2}$ solution gave a dark-brown oily solid. It was then purified by silica gel column chromatography eluting with a $1: 4$ mixture of ethyl acetate and hexane to afford a mixture of isomers a and $\mathbf{c}$ and analytically pure isomer $\mathbf{b}$. Then, analytically pure a and $\mathbf{c}$ were separated by a second silica gel column chromatography using a 1 : 20 mixture of ethyl acetate and $\mathrm{CH}_{2} \mathrm{Cl}_{2}$.

For hydrolysis, each of the samples was dissolved in a mixed acetone $(20 \mathrm{~mL})$ and $1 \mathrm{M} \mathrm{NaOH}$ solution $(0.1 \mathrm{~mL})$, and heated to reflux under $\mathrm{N}_{2}$ for $3 \mathrm{~h}$. After this, the solution was diluted with water $(10 \mathrm{~mL})$ and, then, acidified with $2 \mathrm{M} \mathrm{HCl}$ to $\mathrm{pH} 3$ to afford a brown precipitate. This was collected and washed with water, acetone, and diethylether in sequence, yield: $52 \mathrm{mg}, 32 \%$ for TFRS-80a, $18 \mathrm{mg}, 11 \%$ for TFRS-80b, and $25 \mathrm{mg}, 15 \%$ for TFRS80c.

Spectral data of TFRS-80a. MS (FAB, $\left.{ }^{102} \mathrm{Ru}\right): \mathrm{m} / \mathrm{z} 1588(\mathrm{M}+$ $1)^{+} .{ }^{1} \mathrm{H}$ NMR (400 MHz, d 6 -DMSO, $\left.298 \mathrm{~K}\right): \delta 8.98(\mathrm{~s}, 2 \mathrm{H}), 8.86(\mathrm{~d}, J$ $=9.2 \mathrm{~Hz}, 2 \mathrm{H}), 8.14(\mathrm{~d}, J=6.0 \mathrm{~Hz}, 2 \mathrm{H}), 8.07(\mathrm{~s}, 2 \mathrm{H}), 8.01(\mathrm{~d}, J=$ $8.8 \mathrm{~Hz}, 2 \mathrm{H}), 7.83(\mathrm{~s}, 2 \mathrm{H}), 7.74(\mathrm{~d}, J=6.0 \mathrm{~Hz}, 2 \mathrm{H}), 7.68(\mathrm{~d}, J=4.0$ $\mathrm{Hz}, 2 \mathrm{H}), 7.57$ (d, $J=4.0 \mathrm{~Hz}, 2 \mathrm{H}), 7.53(\mathrm{~d}, J=6.8 \mathrm{~Hz}, 2 \mathrm{H}), 7.21(\mathrm{t}, J$ $=8.4 \mathrm{~Hz}, 2 \mathrm{H}), 7.04(\mathrm{~d}, J=6.4 \mathrm{~Hz}, 2 \mathrm{H}), 6.70(\mathrm{~d}, J=8.4 \mathrm{~Hz}, 4 \mathrm{H})$, $3.99(\mathrm{t}, J=6.4 \mathrm{~Hz}, 8 \mathrm{H}), 1.71(\mathrm{~m}, 8 \mathrm{H}), 1.38(\mathrm{~m}, 8 \mathrm{H}), 1.22(\mathrm{~m}, 16 \mathrm{H})$, $0.74(\mathrm{t}, J=6.8 \mathrm{~Hz}, 12 \mathrm{H}) .{ }^{19} \mathrm{~F}$ NMR $\left(376 \mathrm{MHz}, \mathrm{d}_{6}\right.$-DMSO, $\left.298 \mathrm{~K}\right): \delta$ -60.12 (s, 6F). Anal. calcd for $\mathrm{C}_{82} \mathrm{H}_{82} \mathrm{~F}_{6} \mathrm{~N}_{8} \mathrm{O}_{8} \mathrm{RuS}_{2} \cdot \mathrm{H}_{2} \mathrm{O}$ : C, 61.37; N, 6.98; H, 5.28\%. Found: C, 61.21; N, 6.71; H, 5.44\%.

Spectral data of TFRS-80b. MS (FAB, $\left.{ }^{102} \mathrm{Ru}\right): m / z 1587(\mathrm{M})^{+}$.

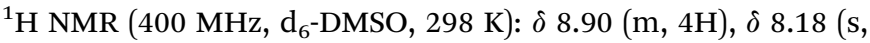
$1 \mathrm{H}), \delta 8.13(\mathrm{~s}, 1 \mathrm{H}), 8.07(\mathrm{~d}, J=8.0 \mathrm{~Hz} 2 \mathrm{H}), 8.01(\mathrm{~m}, 1 \mathrm{H}), 7.83(\mathrm{~s}$, $1 \mathrm{H}), 7.77(\mathrm{~m}, 5 \mathrm{H}), 7.71(\mathrm{~s}, 1 \mathrm{H}), 7.61(\mathrm{t}, J=3.6 \mathrm{~Hz}, 2 \mathrm{H}), 7.51(\mathrm{~d}, J$ $=6.4 \mathrm{~Hz}, 1 \mathrm{H}), 7.45(\mathrm{~d}, J=6.4 \mathrm{~Hz}, 1 \mathrm{H}), 7.39(\mathrm{~d}, J=6.4 \mathrm{~Hz}, 1 \mathrm{H})$, 
$7.33(\mathrm{~d}, J=6.4 \mathrm{~Hz}, 1 \mathrm{H}), 7.24(\mathrm{~m}, 2 \mathrm{H}), 6.77(\mathrm{~d}, J=3.6 \mathrm{~Hz}, 2 \mathrm{H})$, $6.75(\mathrm{~d}, J=4.0 \mathrm{~Hz}, 2 \mathrm{H}), 4.05(\mathrm{~m}, 8 \mathrm{H}), 1.74(\mathrm{~m}, 8 \mathrm{H}), 1.27(\mathrm{~m}, 8 \mathrm{H})$, $1.23(\mathrm{~m}, 16 \mathrm{H}), 0.79(\mathrm{t}, J=6.8 \mathrm{~Hz}, 12 \mathrm{H}) .{ }^{19} \mathrm{~F} \mathrm{NMR}\left(376 \mathrm{MHz}, \mathrm{d}_{6}{ }^{-}\right.$ DMSO, $298 \mathrm{~K}): \delta-57.74(\mathrm{~s}, 3 \mathrm{~F}),-57.79(\mathrm{~s}, 3 \mathrm{~F})$. Anal. calcd for $\mathrm{C}_{82} \mathrm{H}_{82} \mathrm{~F}_{6} \mathrm{~N}_{8} \mathrm{O}_{8} \mathrm{RuS}_{2} \cdot 2 \mathrm{H}_{2} \mathrm{O}: \mathrm{C}, 60.69 ; \mathrm{N}, 7.02 ; \mathrm{H}, 5.34 \%$. Found: C, 60.56; N, 6.74; H, 5.49\%.

Spectral data of TFRS-80c. MS (FAB, $\left.{ }^{102} \mathrm{Ru}\right): m / z 1587(\mathrm{M}){ }^{+} \cdot{ }^{1} \mathrm{H}$

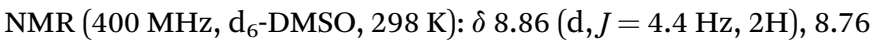
$(\mathrm{s}, 2 \mathrm{H}), 8.06(\mathrm{~s}, 2 \mathrm{H}), 8.02(\mathrm{~d}, J=9.2 \mathrm{~Hz}, 2 \mathrm{H}), 7.91(\mathrm{~d}, J=5.2 \mathrm{~Hz}$, $2 \mathrm{H}), 7.80(\mathrm{~s}, 2 \mathrm{H}), 7.69(\mathrm{~d}, J=3.6 \mathrm{~Hz}, 2 \mathrm{H}), 7.63(\mathrm{~d}, J=5.6 \mathrm{~Hz}, 2 \mathrm{H})$, $7.58(\mathrm{~d}, J=3.6 \mathrm{~Hz}, 2 \mathrm{H}), 7.49(\mathrm{~d}, J=6.4 \mathrm{~Hz}, 2 \mathrm{H}), 7.22(\mathrm{t}, J=8.4$ $\mathrm{Hz}, 2 \mathrm{H}), 7.07$ (d, $J=6.4 \mathrm{~Hz}, 2 \mathrm{H}), 6.72(\mathrm{~d}, J=8.4 \mathrm{~Hz}, 4 \mathrm{H}), 4.00(\mathrm{t}, J$ $=6.0 \mathrm{~Hz}, 8 \mathrm{H}), 1.71(\mathrm{~m}, 8 \mathrm{H}), 1.39(\mathrm{~m}, 8 \mathrm{H}), 1.22(\mathrm{~m}, 16 \mathrm{H}), 0.75(\mathrm{t}, J$ $=6.8 \mathrm{~Hz}, 12 \mathrm{H}) .{ }^{19} \mathrm{~F}$ NMR $\left(376 \mathrm{MHz}, \mathrm{d}_{6}\right.$-DMSO, $\left.298 \mathrm{~K}\right): \delta-57.91$ (s, 6F). Anal. calcd for $\mathrm{C}_{82} \mathrm{H}_{82} \mathrm{~F}_{6} \mathrm{~N}_{8} \mathrm{O}_{8} \mathrm{RuS}_{2} \cdot \mathrm{H}_{2} \mathrm{O}: \mathrm{C}, 61.37 ; \mathrm{N}$, 6.98; H, 5.28\%. Found: C, 61.33; N, 6.75; H, 5.34\%.

\section{Device fabrication}

The cells consisted of a $3.6 \mu \mathrm{m}$ transparent layer of $20 \mathrm{~nm} \mathrm{TiO}_{2}$ nanoparticles, on which was superimposed a second layer, $3.5 \mu \mathrm{m}$ of $400 \mathrm{~nm} \mathrm{TiO}_{2}$ nanoparticles for enhancing light scattering. This double layer film was heated to $500{ }^{\circ} \mathrm{C}$, sintered for $30 \mathrm{~min}$, cooled to $80{ }^{\circ} \mathrm{C}$, and then immersed into the dye solution $(0.3 \mathrm{mM})$ containing $10 \mathrm{vol} \% \mathrm{DMSO}$ and 2 eq. of tetrabutylammonium deoxycholate [TBA][DOC] in anhydrous ethanol for $12 \mathrm{~h}$. The iodine electrolyte I-A contains $0.6 \mathrm{M}$ DMPII (1,2-dimethyl-3-propyl-imidazolium iodide), $0.05 \mathrm{M} \mathrm{I}_{2}$, $0.5 \mathrm{M}$ TBP (4-tert-butylpyridine) in acetonitrile. The cobalt electrolyte Co-phen contains $0.45 \mathrm{M}\left[\mathrm{Co}(\mathrm{phen})_{3}\right][\mathrm{TFSI}]_{2}, 0.15 \mathrm{M}$ $\left[\mathrm{Co}(\text { phen })_{3}\right][\mathrm{TFSI}]_{3}, 0.15 \mathrm{M}$ LiTFSI, and $0.8 \mathrm{M}$ TBP in acetonitrile. The iodine electrolyte I-B contains $0.45 \mathrm{M}$ DMPII, $0.05 \mathrm{M}$ $\mathrm{I}_{2}, 0.15 \mathrm{M}$ LiI, and $0.8 \mathrm{M}$ TBP in acetonitrile. The counter electrodes were coated with an ultra-thin layer of the PVP capped platinum nanoclusters (PVP-Pt) in aqueous solution via a socalled "two-step dip coating” process on FTO glass $(7 \Omega / \mathrm{TEC} 7$, $2.2 \mathrm{~mm}$ thick, Pilkington), followed by a post heating at $325^{\circ} \mathrm{C}$ for 10 min. ${ }^{33}$ The dye sensitized $\mathrm{TiO}_{2}$ electrodes were assembled with Pt counter electrodes by inserting a hot-melt Surlyn film (Meltonix 1170-25, $25 \mu \mathrm{m}$, Solaronix) as spacer, and then heated at $130{ }^{\circ} \mathrm{C}$. The electrolyte was injected into the cell through a predrilled hole at the counter electrode. The hole was sealed with a Surlyn sheet and a thin glass to avoid leakage. All fabricated DSC cells consist of an active area of $5 \times 5 \mathrm{~mm}^{2}$, and the performances were measured using a black metal mask with an aperture area of $4 \times 4 \mathrm{~mm}^{2}$.

\section{Electrochemical characterization of dyes on $\mathrm{TiO}_{2}$}

Conductive FTO glass slides were cleaned with soap, water, deionized water, acetone and ethanol, dried under hot air and $\mathrm{TiO}_{2}$ paste (Dyesol 18 NR-T) was deposited on the FTO glass via doctor blading. The films were sintered at $450{ }^{\circ} \mathrm{C}$ for $30 \mathrm{~min}$; the resulting film thicknesses were $\sim 6 \mu \mathrm{m}$. After cooling, the films were left in the dye bath (0.3 mM in DMSO-EtOH (v/v, $1: 9)$ ) for $30 \mathrm{~h}$, then rinsed in acetonitrile for $1 \mathrm{~min}$. Cyclic voltammetry (CV) measurements were performed using a three-electrode cell with the FTO/dyed- $\mathrm{TiO}_{2}$ film as the working electrode, a Pt rod counter electrode and an $\mathrm{Ag} / \mathrm{AgCl}$ reference electrode. The electrolyte composition was $0.1 \mathrm{M} \mathrm{TBAPF}_{6}$ dissolved in acetonitrile bubbled with nitrogen for $15 \mathrm{~min}$ before the experiment.

\section{Photovoltaic characterization}

Photovoltaic measurements were carried out under a class-AAA solar simulator (Model 11016A, Sun 3000, ABET Technologies) equipped with a $550 \mathrm{~W}$ xenon light source and water-cooling stage $\left(25^{\circ} \mathrm{C}\right)$. The output power density was calibrated to be 100 $\mathrm{mW} \mathrm{cm}^{-2}$ using a certificated KG-5 Si reference cell and with a circular aperture of $8 \mathrm{~mm}$. The current-voltage characteristic of each cell was obtained with a 4-wire sense mode, delay time set as $100 \mathrm{~ms}$ and bias scan from short-circuit to open-circuit by using a Keithley digital source meter (Model 2400). The spectra of the incident photon-to-current conversion efficiency (IPCE) were calculated with the equation $1240 J_{\mathrm{SC}}(\lambda) /(\lambda \operatorname{Pin}(\lambda))$ where $J_{\mathrm{SC}}$ is the short-circuit current density under each monochromatic illumination in units of $\mathrm{A} \mathrm{cm}^{-2}, \lambda$ is the wavelength of incident monochromatic light in units of nanometers, and Pin is the monochromatic light intensity in units of $\mathrm{W} \mathrm{cm}^{-2}$, plotted as a function of incident wavelength with an increment of $10 \mathrm{~nm}$. The current was pre-amplified by a current amplifier (SR570) and measured by Keithley 2400 source meter. It should be noted that 10 sets of $J_{\mathrm{SC}}$ (interval $50 \mathrm{~ms}$ ) were collected sequentially after illuminating the device for 3 seconds and then averaged for calculation of IPCE. A $300 \mathrm{~W}$ Xe lamp (Model 6258, Newport Oriel) combined with an Oriel cornerstone $2601 / 4 \mathrm{~m}$ monochromator (Model 74100) provided a monochromatic beam (dc mode) for the device under test conditions. The beam power intensity was calibrated with a power meter (Model 1936-C, Newport) equipped with a Newport 818-UV photodetector.

\section{Charge extraction and intensity-modulated photovoltage spectroscopy}

Charge extraction was measured with the PGSTAT302N electrochemical workstation (Autolab) at open-circuit condition for the photovoltage of the device to attain a steady state. A red light-emitting diode (LED, $627 \mathrm{~nm}$ ) was attenuated while the device simultaneously switched to a short-circuit condition to measure the excess charges generated in the film. Intensitymodulated photovoltage spectroscopy (IMVS) measurement was conducted using the same electrochemical workstation equipped with a frequency response analyzer (FRA) to drive the red LED. Photovoltage response of the cells was analyzed in the frequency range of $1-10^{4} \mathrm{~Hz}$ and LED supplied the AC (modulation depth $10 \%$ ) perturbation current superimposed on the DC current.

\section{Acknowledgements}

This research was supported by Ministry of Science and technology of Taiwan, MOST 100-2119-M-002-008, and the UK EPSRC Global Grant EP/K004468. YH thanks the China Scholarship Council and the University of Edinburgh for a studentship. 


\section{References}

1 (a) L. M. Goncalves, V. de Zea Bermudez, H. A. Ribeiro and A. M. Mendes, Energy Environ. Sci., 2008, 1, 655; (b) A. Hagfeldt, G. Boschloo, L. Sun, L. Kloo and H. Pettersson, Chem. Rev., 2010, 110, 6595; (c) J.-H. Yum, E. Baranoff, S. Wenger, M. K. Nazeeruddin and M. Grätzel, Energy Environ. Sci., 2011, 4, 842; (d) Y. Bai, I. Mora-Seró, F. De Angelis, J. Bisquert and P. Wang, Chem. Rev., 2014, 114, 10095.

2 (a) S. Mathew, A. Yella, P. Gao, R. Humphry-Baker, F. E. CurchodBasile, N. Ashari-Astani, I. Tavernelli, U. Rothlisberger, M. K. Nazeeruddin and M. Grätzel, Nat. Chem., 2014, 6, 242; (b) A. Yella, C.-L. Mai, S. M. Zakeeruddin, S.-N. Chang, C.-H. Hsieh, C.-Y. Yeh and M. Grätzel, Angew. Chem., Int. Ed., 2014, 53, 2973.

3 (a) A. Mishra, M. K. R. Fischer and P. Bäuerle, Angew. Chem., Int. Ed., 2009, 48, 2474; (b) Z. Ning, Y. Fu and H. Tian, Energy Environ. Sci., 2010, 3, 1170; (c) Y. Wu and W. Zhu, Chem. Soc. Rev., 2013, 42, 2039; (d) Y.-S. Yen, H.-H. Chou, Y.-C. Chen, C.-Y. Hsu and J. T. Lin, J. Mater. Chem., 2012, 22, 8734; (e) Y. Ooyama and Y. Harima, ChemPhysChem, 2012, 13, 4032; (f) S. Ito, H. Miura, S. Uchida, M. Takata, K. Sumioka, P. Liska, P. Comte, P. Pechy and M. Grätzel, Chem. Commun., 2008, 5194; (g) G. Zhang, H. Bala, Y. Cheng, D. Shi, X. Lv, Q. Yu and P. Wang, Chem. Commun., 2009, 2198; (h) Q. Yu, D. Zhou, Y. Shi, X. Si, Y. Wang and P. Wang, Energy Environ. Sci., 2010, 3, 1722; (i) J.-H. Yum, E. Baranoff, F. Kessler, T. Moehl, S. Ahmad, T. Bessho, A. Marchioro, E. Ghadiri, J.-E. Moser, C. Yi, M. K. Nazeeruddin and M. Grätzel, Nat. Commun., 2012, 3, 631.

4 C. Chen, X. Yang, M. Cheng, F. Zhang and L. Sun, ChemSusChem, 2013, 6, 1270.

5 B. Zietz, E. Gabrielsson, V. Johansson, A. M. El-Zohry, L. Sun and L. Kloo, Phys. Chem. Chem. Phys., 2014, 16, 2251.

6 (a) M. Zhang, J. Zhang, Y. Fan, L. Yang, Y. Wang, R. Li and P. Wang, Energy Environ. Sci, 2013, 6, 2939; (b) M. Zhang, Y. Wang, M. Xu, W. Ma, R. Li and P. Wang, Energy Environ. Sci., 2013, 6, 2944.

7 (a) M. K. Nazeeruddin, P. Péchy, T. Renouard, S. M. Zakeeruddin, R. Humphry-Baker, P. Comte, P. Liska, L. Cevey, E. Costa, V. Shklover, L. Spiccia, G. B. Deacon, C. A. Bignozzi and M. Grätzel, J. Am. Chem. Soc., 2001, 123, 1613; (b) J.-H. Yum, I. Jung, C. Baik, J. Ko, M. K. Nazeeruddin and M. Grätzel, Energy Environ. Sci., 2009, 2, 100; (c) Y. Cao, Y. Bai, Q. Yu, Y. Cheng, S. Liu, D. Shi, F. Gao and P. Wang, J. Phys. Chem. C, 2009, 113, 6290; (d) L. H. Nguyen, H. K. Mulmudi, D. Sabba, S. A. Kulkarni, S. K. Batabyal, K. Nonomura, M. Grätzel and S. G. Mhaisalkar, Phys. Chem. Chem. Phys., 2012, 14, 16182; (e) S.-W. Wang, C.-C. Chou, F.-C. Hu, K.-L. Wu, Y. Chi, J. N. Clifford, E. J. Palomares, S.-H. Liun, P.-T. Chou, T. C. Wei and T. Y. Hsiao, J. Mater. Chem. A, 2014, 2, 17618. 8 A. Hinsch, W. Veurman, H. Brandt, K. Flarup Jensen and S. Mastroianni , ChemPhysChem, 2014, 15, 1076.
9 (a) S. H. Wadman, J. M. Kroon, K. Bakker, M. Lutz, A. L. Spek, G. P. M. van Klink and G. van Koten, Chem. Commun., 2007, 1907; (b) S. H. Wadman, J. M. Kroon, K. Bakker, R. W. A. Havenith, G. P. M. van Klink and G. van Koten, Organometallics, 2010, 29, 1569.

10 (a) T. Bessho, E. Yoneda, J.-H. Yum, M. Guglielmi, I. Tavernelli, H. Imai, U. Rothlisberger, M. K. Nazeeruddin and M. Grätzel, J. Am. Chem. Soc., 2009, 131, 5930; (b) F. De Angelis, S. Fantacci, A. Selloni, M. K. Nazeeruddin and M. Grätzel, J. Phys. Chem. C, 2010, 114, 6054.

11 (a) P. G. Bomben, T. J. Gordon, E. Schott and C. P. Berlinguette, Angew. Chem., Int. Ed., 2011, 50, 10682; (b) P. G. Bomben, K. C. D. Robson, B. D. Koivisto and C. P. Berlinguette, Coord. Chem. Rev., 2012, 256, 1438; (c) K. C. D. Robson, P. G. Bomben and C. P. Berlinguette, Dalton Trans., 2012, 41, 7814; (d) S. Sinn, B. Schulze, C. Friebe, D. G. Brown, M. Jäger, E. Altuntaş, J. Kübel, O. Guntner, C. P. Berlinguette, B. Dietzek and U. S. Schubert, Inorg. Chem., 2014, 53, 2083.

12 (a) B.-S. Chen, K. Chen, Y.-H. Hong, W.-H. Liu, T.-H. Li, C.-H. Lai, P.-T. Chou, Y. Chi and G.-H. Lee, Chem. Commun., 2009, 5844; (b) K.-L. Wu, H.-C. Hsu, K. Chen, Y. Chi, M.-W. Chung, W.-H. Liu and P.-T. Chou, Chem. Commun., 2010, 46, 5124; (c) Y. Chi, B. Tong and P.-T. Chou, Coord. Chem. Rev., 2014, 281, 1.

13 (a) C.-C. Chou, K.-L. Wu, Y. Chi, W.-P. Hu, S. J. Yu, G.-H. Lee, C.-L. Lin and P.-T. Chou, Angew. Chem., Int. Ed., 2011, 50, 2054; (b) K.-L. Wu, S.-T. Ho, C.-C. Chou, Y.-C. Chang, H.-A. Pan, Y. Chi and P.-T. Chou, Angew. Chem., Int. Ed., 2012, 51, 5642; (c) C.-C. Chou, F.-C. Hu, H.-H. Yeh, H.-P. Wu, Y. Chi, J. N. Clifford, E. Palomares, S.-H. Liu, P.-T. Chou and G.-H. Lee, Angew. Chem., Int. Ed., 2014, 53, 178.

14 (a) C.-W. Hsu, S.-T. Ho, K.-L. Wu, Y. Chi, S.-H. Liu and P.-T. Chou, Energy Environ. Sci., 2012, 5, 7549; (b) C.-C. Chou, P.-H. Chen, F.-C. Hu, Y. Chi, S.-T. Ho, J.-J. Kai, S.-H. Liu and P.-T. Chou, J. Mater. Chem. A, 2014, 2, 5418.

15 (a) K.-L. Wu, W.-P. Ku, J. N. Clifford, E. Palomares, S.-T. Ho, Y. Chi, S.-H. Liu, P.-T. Chou, M. K. Nazeeruddin and M. Grätzel, Energy Environ. Sci., 2013, 6, 859; (b) S.-W. Wang, K.-L. Wu, E. Ghadiri, M. G. Lobello, S.-T. Ho, Y. Chi, J.-E. Moser, F. De Angelis, M. Grätzel and M. K. Nazeeruddin, Chem. Sci., 2013, 4, 2423.

16 K.-L. Wu, J. N. Clifford, S.-W. Wang, Y. Aswani, E. Palomares, M. G. Lobello, E. Mosconi, F. De Angelis, W.-P. Ku, Y. Chi, M. K. Nazeeruddin and M. Grätzel, ChemSusChem, 2014, 7, 2930.

17 F.-C. Hu, S.-W. Wang, Y. Chi, N. Robertson, T. Hewat, Y. Hu, S.-H. Liu, P.-T. Chou, P.-F. Yang and H.-W. Lin, ChemPhysChem, 2014, 15, 1207.

18 (a) C.-L. Wang, J.-Y. Hu, C.-H. Wu, H.-H. Kuo, Y.-C. Chang, Z.-J. Lan, H.-P. Wu, E. Wei-Guang Diau and C.-Y. Lin, Energy Environ. Sci., 2014, 7, 1392; (b) Z. Wang, H. Wang, M. Liang, Y. Tan, F. Cheng, Z. Sun and S. Xue, ACS Appl. Mater. Interfaces, 2014, 6, 5768; (c) J. Yang, P. Ganesan, J. Teuscher, T. Moehl, Y. J. Kim, C. Yi, P. Comte, K. Pei, T. W. Holcombe, M. K. Nazeeruddin, J. Hua, 
S. M. Zakeeruddin, H. Tian and M. Grätzel, J. Am. Chem. Soc., 2014, 136, 5722.

19 F. Gao, Y. Wang, D. Shi, J. Zhang, M. Wang, X. Jing, R. Humphry-Baker, P. Wang, S. M. Zakeeruddin and M. Grätzel, J. Am. Chem. Soc., 2008, 130, 10720.

20 F. Matar, T. H. Ghaddar, K. Walley, T. DosSantos, J. R. Durrant and B. O'Regan, J. Mater. Chem., 2008, 18, 4246.

21 (a) S.-Q. Fan, C. Kim, B. Fang, K.-X. Liao, G.-J. Yang, C.-J. Li, J.-J. Kim and J. Ko, J. Phys. Chem. C, 2011, 115, 7747; (b) H. Ozawa, R. Shimizu and H. Arakawa, RSC Adv., 2012, 2, 3198; (c) L. Han, A. Islam, H. Chen, C. Malapaka, B. Chiranjeevi, S. Zhang, X. Yang and M. Yanagida, Energy Environ. Sci., 2012, 5, 6057.

22 (a) M. Liang and J. Chen, Chem. Soc. Rev., 2013, 42, 3453; (b) R. Stalder, D. Xie, A. Islam, L. Han, J. R. Reynolds and K. S. Schanze, ACS Appl. Mater. Interfaces, 2014, 6, 8715.

23 (a) X. Li, M. K. Nazeeruddin, M. Thelakkat, P. R. F. Barnes, R. Vilar and J. R. Durrant, Phys. Chem. Chem. Phys., 2011, 13, 1575; (b) D. Moia, V. Vaissier, I. Lopez-Duarte, T. Torres, M. K. Nazeeruddin, B. C. O'Regan, J. Nelson and P. R. F. Barnes, Chem. Sci., 2014, 5, 281.

24 R. Jiang, A. Anderson, P. R. F. Barnes, L. Xiaoe, C. Law and B. C. O'Regan, J. Mater. Chem. A, 2014, 2, 4751.

25 J.-H. Yum, T. Moehl, J. Yoon, A. K. Chandiran, F. Kessler, P. Gratia and M. Grätzel, J. Phys. Chem. C, 2014, 118, 16799.

26 (a) S. Archer and J. A. Weinstein, Coord. Chem. Rev., 2012, 256, 2530; (b) L.-L. Li and E. W.-G. Diau, Chem. Soc. Rev., 2013, 42, 291.
27 (a) L. E. Polander, A. Yella, B. F. E. Curchod, A. N. Ashari, J. Teuscher, R. Scopelliti, P. Gao, S. Mathew, J.-E. Moser, I. Tavernelli, U. Rothlisberger, M. Gratzel, M. K. Nazeeruddin and J. Frey, Angew. Chem., Int. Ed., 2013, 52, 8731; (b) Y. Liu, J. R. Jennings, X. Wang and Q. Wang, Phys. Chem. Chem. Phys., 2013, 15, 6170; (c) Y. Liu, J. R. Jennings, Y. Huang, Q. Wang, S. M. Zakeeruddin and M. Grätzel, J. Phys. Chem. C, 2011, 115, 18847.

28 S. A. Kumar, M. Urbani, M. Medel, M. Ince, D. GonzálezRodríguez, A. K. Chandiran, A. N. Bhaskarwar, T. Torres, M. K. Nazeeruddin and M. Grätzel, J. Phys. Chem. Lett., 2014, 5, 501.

29 (a) Q. Feng, X. Jia, G. Zhou and Z.-S. Wang, Chem. Commun., 2013, 49, 7445; (b) H. Ellis, S. K. Eriksson, S. M. Feldt, E. Gabrielsson, P. W. Lohse, R. Lindblad, L. Sun, H. Rensmo, G. Boschloo and A. Hagfeldt, J. Phys. Chem. C, 2013, 117, 21029; (c) L. Cabau, L. Pelleja, J. N. Clifford, C. V. Kumar and E. Palomares, J. Mater. Chem. A, 2013, 1, 8994.

30 M. Xu, M. Zhang, M. Pastore, R. Li, F. De Angelis and P. Wang, Chem. Sci., 2012, 3, 976.

31 N. Cai, J. Zhang, M. Xu, M. Zhang and P. Wang, Adv. Funct. Mater., 2013, 23, 3539.

32 T. Moehl, H. N. Tsao, K.-L. Wu, H.-C. Hsu, Y. Chi, E. Ronca, F. De Angelis, M. K. Nazeeruddin and M. Grätzel, Chem. Mater., 2013, 25, 4497.

33 T. C. Wei, C. C. Wan and Y. Y. Wang, Appl. Phys. Lett., 2006, 88, 103122. 